\title{
Kolme erityistä seikkaa, joista kirjastoammattilaisen on syytä Eduskunnan kirjastosta tietämän
}

\author{
Antti Virrankoski
}

\begin{abstract}
Aurorankatu kuudessa Etu-Töölössä Eduskuntatalon takana Taidehallin ja Ostrobotnian välissä sijaitsee yksi Helsingin helmistä. Eduskunnan 1978 valmistuneessa laajennusosassa toimiva Eduskunnan kirjasto on kirjastomaailmassa erityinen tapaus, jonka moni tietää mutta jossa yllättävän harva kirjastoammattilainenkaan on koskaan käynyt. Onhan Helsinki suurelle osalle valtakuntaa melko syrjäinen rannikkokaupunki ja jopa monelle töölöläisille kirjaston tarkka sijainti on hieman mysteeri. On nimittäin myönnettävä, että kirjasto ei erityisemmin huuda olemassaolostaan korskealla ulkonäöllään tai kiljuvilla valomainoksillaan. On siis paikallaan tähdentää, mitkä ovat kolme keskeisintä erityspiirrettä, jotka antaisivat kirjastoammattilaiselle mitä mainioimman syyn tutustua kirjastoon lähemmin.
\end{abstract}

\section{Avoin parlamenttikirjasto on harvinaisuus}

Kirjastolaitos on monin tavoin yhteiskuntamme avoimuuden ja tasavertaisuuden kauneimpia ilmentymiä. Eduskunnassa on jo yli vuosisadan toiminut tieteellinen erikoiskirjasto, johon kenellä tahansa on pääsy - yhteiskunnallisesta asemasta, kansallisuudesta, iästä, sukupuolesta, varallisuudesta ja tiedontarpeesta riippumatta. Parlamenttikirjaston avoimuus on kansainvälisesti vertailtuna perin harvinaislaatuista, sillä vain noin parissakymmenessä maassa on avoin pääsy parlamentin kirjastoon. Meillä ei tarvitse kuin astua ovesta sisään ja kokoelmat, tilat, palvelut ja laitteet ovat kaikkien käytettävissä. Eduskunta-asiakkaiden, tutkijoiden, lakiasiaintoimistojen ja median edustajien lisäksi kirjastossa käy opiskelijoita, lähiseudun asukkaita ja joskus jopa koululaisia tekemässä läksyjään.

Tavallaan Eduskunnan kirjasto on etutöölöläisten oma lähikirjasto lehtilukusaleineen ja tietokoneineen. Avoimuus ja lähestyttävyys ovat sekä sellaisenaan arvokkaita asioita mutta myös juuri se näkökulma, jonka kirjaston henkilökunta ha- luaisi yleisemmin tiettäväksi. Onhan avoimuudella pitkät perinteetkin, sillä kirjastoa on voinut kuka tahansa käyttää jo vuodesta 1913 alkaen.

\section{Kirjaston ja arkiston kokoelmat hakevat vertaistaan}

Eduskunnan kirjaston toinen erityispiirre on kiistaton vahvuus traditionaalisena kokoelmakirjastona. Kun muualla tieteellisissä kirjastoissa ja erikoiskirjastoissa on viime vuosina jouduttu tekemään kipeitä leikkauksia hankintaresursseihin, eduskunnan kirjasto on pystynyt ylläpitämään ja kehittämään kokoelmaansa pitkälti entisen keskuskirjastostatuksensa mukaisesti. Näin esimerkiksi kotimaisen juridisen kirjallisuuden osalta kokoelma on perin kattava eikä yhteiskuntatieteellinen kokoelma paljoa jälkeen jää. Kokoelman kova ydin on sekä kotimaiset että kansainväliset virallisjulkaisut ja asiakirjat. Suomen painetut valtiopäiväasiakirjat säätyvaltiopäiviltä lähtien kuuluvat Eduskunnan kirjaston ja arkiston kokoelmiin. Lisäksi kysyttyä aineistoa ovat muun muassa valiokuntien asiantuntijoiden asiantuntijalausunnot. 


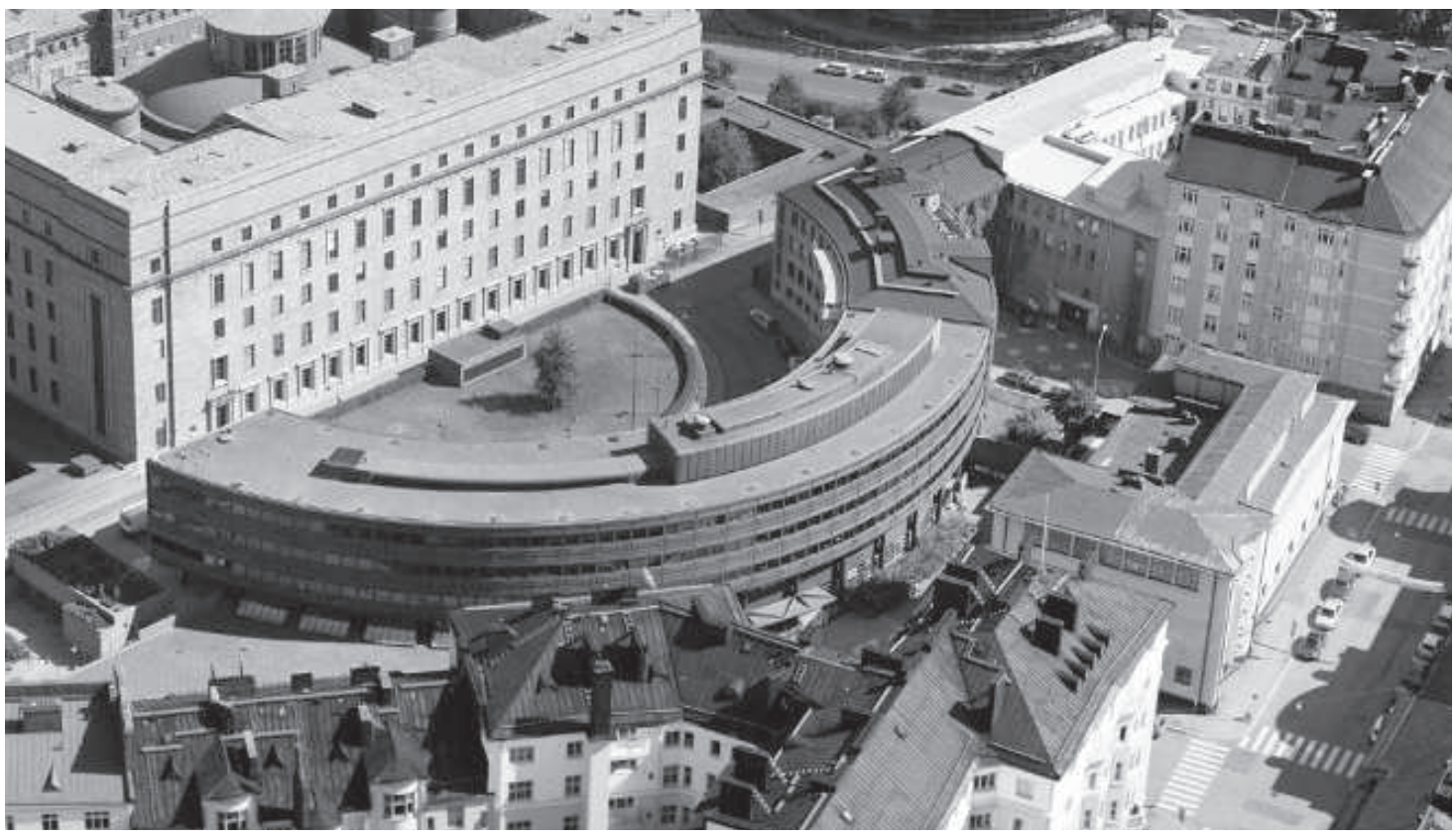

Kansainvälisten järjestöjen aineiston osalta Eduskunnan kirjasto toimii erikoiskirjastona, jonka tehtävänä on välittää tietoa järjestöjen toiminnasta. Edustettuna ovat erityisesti YK:n ja sen erityisjärjestöjen, kuten ILOn, IMF:n, IMO:n sekä Kansainliiton asiakirjat ja julkaisut. Myös Euroopan neuvoston, OECD:n, WTO:n, ETYJ:n, Pohjoismaiden neuvoston, Inter-Parliamentary Unionin (IPU) ja Asian Development Bankin (ADB) asiakirjoista ja julkaisuista on kattava kokoelma.

Kokoelma on kirjastossa siinä määrin mittava, että erikoiskirjastojen joukossa Eduskunnan kirjasto näyttäytyy hyvinkin täysimittaisena tieteellisenä kirjastona, joka tarjoaa erityisesti yhteiskuntatieteen ja oikeustieteen tutkimukselle erinomaisen tietoresurssin, mikä kaukopalvelun kautta on käytössä koko maan laajuisesti ja kansainvälisestikin.

\section{Rauhallista tilaa opiskelulle, tutkimukselle ja arkipäivän tiedonhankinnalle}

Moni muistelee kaiholla aikaa, jolloin kirjasto tarkoitti hiljaisuutta, kuiskauksia ja hillittyjä askelei- ta. Yhteiskunnan muutoksen mukana myös kirjastot ovat sopeutuneet erilaisten ihmisten tarpeisiin käyttää tilaa ja palveluita. Huolimatta julkisuudessa paljon esille nostetusta huolesta ja vaaliteemoiksikin kiirineistä keskusteluista, kirjastot eivät ole hylänneet rauhallisia tiloja ja hiljaisia lukusaleja. Eduskunnan kirjastossakin työasematyöskentely on jo pitkään kuulunut asiakkaiden arkeen, mutta perinteinen kirjaston rauha vallitsee edelleenkin. Tunnelmaltaan ja arkkitehtuuriltaan kirjasto on hyvällä tavalla 'jämähtänyt' 70-luvulle, mikä luo aivan omanlaisensa olosuhteet työskentelylle - ylioppilaskirjoituksiin lukemiselle, tenttiin valmistautumiselle, journalistiselle tiedonhankinnalle, yleistiedon kartuttamiselle, kiinnostuksen tyydyttämiselle tai vaikka maailmanpolitiikan seuraamiselle Financial Timesin avulla.

Aivan erityinen piirre kirjastossa on tutkijoille varattu oma työskentelytila, johon puolivuosittain voi anoa käyttöoikeutta, jos tutkimus kohdistuu kirjaston edustamiin aloihin ja aineistoihin. Paikkoja on rajallinen määrä ja halukkaita olisi aina enemmän paikkoja on tarjolla. Tutkija saa pitää paikkansa halutessaan kahden vuoden ajan, jona 
aikana nämä erikoisasiakkaat tulevat hyvin tutuiksi. Erityisen hienoa on nähdä, kun joku tutkijoistamme saa näkyvyyttä mediassa ja pääsee jakamaan asiantuntijuuttaan yhteiskuntamme hyväksi. Silloin kirjasto voi tuntea vaikuttaneensa ja tukeneensa yhteiskunnallista keskustelua.

\section{Tietoa kirjoittajasta:}

Antti Virrankoski

Palvelujohtaja

Eduskunnan kirjasto

antti.virrankoski@eduskunta.fi

\section{UUTISIA}

\section{Suomen kirjastoseuran selvitys:}

Kirjasto tekee pienellä rahalla paljon syrjäytymisen ehkäisemiseksi Lukutaidon tukemisesta saatavat säästöt ovat miljoonaluokkaa, kertoo tuore Suomen kirjastoseuran ja Finlands svenska biblioteksföreningin teettämä selvitys.

Tuoreen selvityksen mukaan kirjasto tavoittaa 97 prosenttia 10-14-vuotiaista lapsista ja nuorista ja 66 prosenttia koko väestöstä. Kirjastosta lainataan vuodessa 68 miljoonaa kirjaa. Vastaavasti vuosittain myydään 19 miljoonaa kirjaa, eli kirjasto on keskeinen lukutaidon ylläpitäjä. Lisäksi kirjastoissa järjestetään vuosittain 900000 tapahtumaa, mikä on enemmän kuin koskaan aiemmin.

Hyvä lukutaito on tutkitusti tehokas apu työllistymiseen ja syrjäytymisen ehkäisyyn. Lukutaidon tukemisesta saatavat sästöt ovat varovaistenkin arvioiden mukaan miljoonia euroja. Kirjasto opettaa kansalaisille digitaitoja. Noin 350000 ihmistä saa kirjaston kautta vuosittain koulutusta. Lisäksi kirjasto tarjoaa nykyään yhä useammalle pk-yrittäjälle ja freelancerille paikan tehdä työtä.

Kansainvälisten arvioiden mukaan yksi euro kirjastolle hyödyttää yhteiskuntaa kolmella - neljällä eurolla. Kirjastot maksavat Suomelle 330 miljoonaa euroa vuodessa. Suurin osa kuluista maksetaan kuntien budjetista. Kirjaston osuus kunnan menoista on 1,1 prosenttia.

\section{Kaukopalvelukäsikirja päivitetty}

STKS:n aineiston saatavuus -työryhmä on päivittänyt verkosta löytyvän kaukopalvelukäsikirjan. Kaukopalvelun käsikirja on tarkoitettu lyhyeksi johdannoksi kaukopalveluun ja tiiviiksi tietopaketiksi niille, jotka eivät kaukopalvelua entuudestaan tunne. Käsikirjaan on pyritty kirjaamaan kaukopalvelun perusteita, sen työvälineitä ja toimintamalleja. Teknisiä ohjeita, yhteystietoja tai muita ajassa muuttuvia tietoja ei käsikirjassa ole.

Alkuperäinen kotimaisen kaukopalvelun käsikirja ilmestyi painettuna 1995. Nykyisen verkkoversion sisältöjä on päivitetty viimeksi keväällä 2017 ja sen toimittamisesta vastaa Suomen Tieteellisen Kirjastoseuran Aineiston saatavuus -työryhmä.

Käsikirja on hyvä apuväline myös heille jotka tekevät kaukopalvelua satunnaisesti tai muun kirjastotyön ohessa.

https://www.kirjastot.fi/kaukopalvelun-kasikirja 